\title{
The hindu temple as a machine, or, the western machine as a temple
}

\section{Bryan Pfaffenberger}

\section{(2) OpenEdition \\ 1 Journals}

Electronic version

URL: https://journals.openedition.org/tc/732

DOI: $10.4000 /$ tc.732

ISSN: 1952-420X

Publisher

Éditions de l'EHESS

\section{Printed version}

Date of publication: 1 November 1991

ISSN: 0248-6016

\section{Electronic reference}

Bryan Pfaffenberger, "The hindu temple as a machine, or, the western machine as a temple",

Techniques \& Culture [Online], 16 | 1991, Online since 10 January 2006, connection on 29 September 2022. URL: http://journals.openedition.org/tc/732 ; DOI: https://doi.org/10.4000/tc.732

This text was automatically generated on 29 September 2022.

All rights reserved 
The hindu temple as a machine, or, the western machine as a temple

Bryan Pfaffenberger 